\title{
Increased productivity of a flock of sheep using modern methods of reproduction
}

\author{
G. LOUAULT, J. REMBLIĖRE and C. CORNU (*) \\ Lycée Agricole de Tours-Fondettes - 37230 Luynes \\ (*) Station de Physiologie de la Reproduction, \\ Centre de Recherches de Tours, I.N.R.A., Nouzilly 37380 Monnaie (France)
}

Since 1970, the sheep flock at the Lycée Agricole of Tours-Fondettes has used an intensive reproduction system comprising two mating periods:

I) Spring: three waves of a progestagen (FGA)-PMSG artificial insemination treatment are used on the flock to maximize conception;

2) Autumn: hand-mating for all dry ewes; artificial insemination after induction of cestrus in lactating ewes on 3 occasions.

Production is precisely planned using early diagnosis of pregnancy and induction of parturition with dexamethasone.

With this method, productivity (lambs alive 5 days after birth) is $160 \mathrm{p}$. I oo females (older than 7 months) per year as compared with the traditional level of 90 p. 100 ewes per year. Romanov $\times$ Charmoise ewes being introduced into the flock in 1974, productivity is now about 300 lambs p. Ioo ewes per year.

The flock is housed during the winter and at night, and depastured during the daytime in summer. This study shows that modern methods of reproduction (I.N.R.A. method) may be integrated with the traditional management systems.

\section{Factors affecting lamb perinatal mortality}

\author{
M. J. BOSC and C. CORNU \\ Station de Physiologie de la Reproduction, \\ Centre de Recherches de Tours, I.N.R.A., \\ Nouzilly 37380 Monnaie (France)
}

Ile-de-France, Préalpes du Sud and Romanov ewes have been observed for lamb viability over a period of several years. These animals are submitted to an intensive programme of reproduction in zero grazing conditions. At birth there is a high rate of abnormal presentation of lambs; this depends on breed and prolificacy, and on parity as concerns posterior presentation. The latter seems to be associated with a higher mortality rate. The sex of the lamb and the parity of the mother have inverse effect, according to the breed. The classical effect of prolificacy, weight of the newborn, and duration of pregnancy are defined for each breed. 